\title{
Effect of Credit Risk Management on Financial Performance of Nigerian Listed Deposit Money Banks
}

\author{
KAJOLA Sunday Olugboyega ${ }^{\#}$ \\ Department of Accounting \\ Federal University of Agriculture, Abeokuta, \\ Nigeria. \\ ADEDEJI Samuel Babatunji \\ Department of Accounting \\ Olabisi Onabanjo University, Ago-Iwoye, Nigeria.
}

\author{
OLABISI Jayeola \\ Department of Accounting \\ Federal University of Agriculture, Abeokuta, \\ Nigeria. \\ BABATOLU Ayorinde Tobi \\ Department of Accounting \\ Federal University of Agriculture, Abeokuta,
}

Nigeria.

\#corresponding author.

\begin{abstract}
Deposit money banks are concerned with the provision of credit facilities in form of loans and advances to customers. These loans and advances are expected to be repaid by customers in line with the agreement reached with their bankers. Customers' default in the repayment of loans and advances at the agreed period may lead to bad and doubtful debts and this can affect the financial health, profitability and going concern status of the bank. This study empirically explored the effect of credit risk management on the financial performance of ten listed deposit money banks in Nigeria for the period, 2005-2016. Credit risk management, the independent variable, was surrogated by three parameters- Non-performing Loan to total Loan Ratio (NPLLR); Non-performing Loan to total Deposit Ratio (NPLDR) and Capital Adequacy Ratio (CAR). Return on asset (ROA) and Return on equity (ROE) was used as proxies for financial performance. Using the Random effects generalised least squares (GLS) regression as data estimation technique, the study revealed that all the three credit risk parameters have a significant relationship with ROA and ROE $(p<0.05)$. Based on the findings, the study recommended that the management of deposit money banks should develop rigorous and robust credit policies that will enable banks to effectively assess the creditworthiness of their customers. The regulatory agencies should also come up with modern credit risk measurements, identification and control. Prompt and necessary action should also be taken against the management of any bank that flouts their credit risk guidelines in order to avoid unpleasant distress in the financial system.
\end{abstract}

Keywords: Bank, Credit management, Firm performance, Loan, Risk.

\subsection{Introduction}

Banks are an integral part of a country's development. Their major role in any economy is the ability to mobilize funds from surplus unit to the deficit unit through lending activities. When loans and advances granted are paid promptly, this serves as an impetus for additional credits to be provided to existing and future customers. However, in every imperfect market there exist some risks that affect the repayment of the credit facility by banks' customers. Basel (2001) identified credit risks as the major form of risks that affect financial institutions.

Credit risk can occur from two major sources- the bank management (through lack of thorough investigation of loan requests of the customer) and the customer (having hidden agenda, unknown to the bank, on the credit facility requested for). These combined activities of banks' management and customers lead to non-payment of 
both the principal sum and interest as and when due. The loans that are not paid at the agreed date are known as non-performing loans.

The non-performing loan, especially when it is deemed lost, is the greatest threat to the profitability and survival of banks. When it is lost, it will hinder banks from achieving their set target and can also lead to organisational failures (Greuning\&Bratanovic, 2003, Kolapo, Ayeni, \&Oke, 2012 and Poudel, 2012).

Banks' management recognises the fact that mitigating the occurrence of the risk of non-performing loans can only come from the institution of pragmatic credit administration policy and the policy must incorporate risk assessment and follow up mechanism.

Capital adequacy as an ingredient of credit risk measure depicts the extent to which shareholders funds cover non-performing loans. It helps to prevent bank failure if it is properly controlled and managed. The prescribed ratio is usually provided by the regulatory institution, such as the Central Bank of Nigeria (CBN).

Profitability is essential for the survival of any firm that is in business and banks do rely on interest income generated from loans and advances extended to their customers. Thus, non-performing loans, advances and bad debt can erode the profitability of banks.

The primary objective of the current work is to empirically explore the relationship between credit risk management practices of Nigerian listed deposit money banks and financial performance. A growing body of literature in this aspect of financial management is available in developed countries but not much has been discussed in developing countries, especially in Nigeria. Due to different methodologies, particularly in the definition of proxies used as surrogates for credit risk management, mixed results were produced by prior studies. The present study tries to mitigate the above shortcomings in the literature by utilising ten (out of 15) deposit money banks in the Nigerian business environment to test the relationship between the two variables.

\subsection{LITERATURE REVIEW}

\subsubsection{Theoretical Framework}

\section{Asymmetric Information Theory}

Information asymmetry in a financial market arises when a borrower who obtains loan facility from a bank has better information about the expected risks and returns associated with the investment project for which the fund was sought (Edwards \& Turnbull 1994). The lender may not have sufficient information about the borrower. This theory submits that banks face twin problems of moral hazard (monitoring borrower's behaviour) and adverse selection (making errors in the lending decision) whenever customers' loan requests are being processed.

\section{Signalling Hypothesis}

This hypothesis, according to Olokoyo (2011), Okoye and Eze (2013) and Lawal, Abiola and Ikhu-Omoregbe (2017), suggests that banks demand collateral from reputable customers who request for the loan facility. This is necessary in order to protect customers' deposits and at the same time send a signal to the banks that they (reputable companies) belong to the less risky class of customers. Furthermore, high-risk customers are also requested to provide huge collateral for loan facility and banks do charge high-interest rates to cover for the high risk of the customers' request.

\subsubsection{Empirical Review}

A significant number of studies exist in the extant literature which examined the effects of credit risk management on the profitability of banks in both developed and developing economies. Some of these studies are discussed in turn.

Kurawa and Garba (2014) studied the effect of credit risk management on the profitability of 6 Nigerian banks for the period 2002 to 2011. Using random-effect generalized least squares (GLS) regression techniques as a tool of analysis; findings established a positive and significant relationship between two credit risk variables (default rate and cost per loan asset) and profitability (ROA) of Nigerian banks.

Idowu and Awoyemi (2014) investigated the impact of credit risk management on the performance of 7 commercial banks in Nigeria for the period 2005-2011. A panel regression model was adopted as an estimation technique. Findings suggested that non-performing loan (a measure of credit risk) has a negative and significant effect on the profitability of Nigerian commercial banks. 
Uwuigbe, Uwuigbe and Oyewo (2015) critically examined the effects of credit management on banks' performance in Nigeria. A sample of 10 banks was used for 2007-2011. The study adopted panel linear regression methodology in the estimation of the coefficient of the variables. Results revealed that nonperforming loans and bad debt ratios have a significant and inverse effect on the performance of banks in Nigeria. Furthermore, the relationship between secured and unsecured loan ratio and bank's performance was insignificant.

Kodithuwakku (2015) explored the relationship between credit risk management and performance of 8 commercial banks in Sri Lanka for a five year period from 2009 to 2013. Return on asset (ROA) was used as performance surrogate while four variables (loan provision to total loan, loan provision to non-performing loans, loan provision to total assets and non-performing loans to total loans) were used as parameters of credit risk. Regression results revealed that non-performing loans and provisions have a negative impact on the financial performance of the institutions.

Alshatti (2015) assessed the effect of credit risk management on the financial performance of 13 commercial banks in Jordan during the period of 2005 to 2013. Findings showed a significant positive impact of credit management (represented by the ratio of non-performing loans to gross loans) on financial performance (ROA) of the banks.

Asfaw and Veni (2015) investigated the level of credit risk management practice of Ethiopian public and private commercial banks. Using a descriptive survey research approach, the findings revealed that four aspects of Basel's credit risk management principles significantly explain the level of variation on credit risk management practice of banks in Ethiopia.

Singh (2015) used data from selected public and private commercial banks in India for the financial years 2002/2003 to 2012/2013 to determine the relationship between ROA (performance indicator) and two credit risk indicators (CAR and NPL). With the use of least squares as estimation techniques, the results produced mixed results for both the private and public commercial banks.

Muriithi, Waweru and Muturi (2016) assessed the relationship between credit risk and profitability of 43 Kenyan commercial banks for the year 2014. By using both fixed effects estimation and generalized method of moments (GMM) techniques, results showed that credit risk variable has a negative and significant relationship with the financial performance of the sampled banks.

Aykut (2016) assessed the effect of credit and market risk on bank performance of quoted Turkish banks. With the use of generalized autoregressive conditional heteroscedastic approach for weekly data generated between $18^{\text {th }}$ January 2002 and $30^{\text {th }}$ October 2015, the results suggested that credit risk has an inverse and foreign exchange has a direct effect on banking sector profitability.

Ogbulu and Eze (2016) studied the influence of credit risk management on the performance of selected Nigerian deposit money banks for the period 1989 to 2013. Using Error Correction Model (ECM) and Granger causality techniques, the findings of the study revealed that the selected credit risk indicators under study significantly impact on the financial performance of the banks.

Kani (2017) examined the impact of credit risk on banking performance in the member states of the West African Economic and Monetary Union (WAEMU). The analysis involved 20 banks over a 9-year period (20072015). With the use of individual-specific effects models, the results show a negative and significant effect of credit risk on bank performance measured by ROA.

Annor and Obeng (2017) explored the impact of credit risk management on the profitability of 6 selected commercial banks listed on the Ghana stock exchange. Using random effect model within the panel estimation technique, the findings showed capital adequacy ratio had a positive relationship with a bank's profitability, non-performing loans, loan loss provisions ratio and loan to asset ratio showed a statistically significant negative relationship with the profitability of a bank.

Harcourt (2017) analyzed the impact of credit risk management on the performance of deposit money banks in Nigeria using over parameterised and parsimonious error correction model and Granger causality for the period 1989 to 2014. Findings suggested a significant relationship between credit management parameters and the performance of deposit money banks.

Okere, Isiaka and Ogunlowore (2018) studied the impact risk management has on the financial performance of 10 Nigerian deposit money banks. Results from the panel regression showed a positive and significant relationship between risk management and financial performance of the sampled banks. 


\subsection{Research Design}

The study adopted an ex-post facto research design as past data in the form of secondary data were utilized. It is also empiric in nature.

\subsection{Source of Data}

Data for the period of study, 2005-2016, were mainly from a secondary source and obtained primarily from published annual reports and accounts of the banks sampled for the study.

\subsection{Population, Sample and Sampling Technique}

The target population for the study as at $31^{\text {st }}$ August 2018 was 15 listed deposit money banks out of which 10 banks were selected as a sample through judgemental sampling technique (guided by the availability of relevant data used for the study).

\subsection{Variable Description and Measurement}

Table 1 presents the study variables and their measurements.

Table 1: Measurement of Variables

\begin{tabular}{|c|c|c|c|}
\hline Variable & Abbreviation & Type & Measurement \\
\hline Return on Asset & ROA & Dependent & $\frac{\text { Profit after tax }}{\text { Total assets }}$ \\
\hline Return on Equity & ROE & Dependent & $\frac{\text { Profit after tax }}{\text { Number of equity shares in issue }}$ \\
\hline $\begin{array}{l}\text { Non-performing to } \\
\text { total loan ratio }\end{array}$ & NPLLR & Independent & $\begin{array}{l}\text { Non-performing loans } \\
\text { The total amount of loans and advances }\end{array}$ \\
\hline $\begin{array}{l}\text { Non-performing to } \\
\text { total deposit ratio }\end{array}$ & NPLDR & Independent & $\frac{\text { Non-performing loans }}{\text { Total deposits }}$ \\
\hline Capital adequacy ratio & CAR & Independent & $\frac{\text { Shareholders' fund }}{\text { Total assets }}$ \\
\hline Leverage ratio & LEV & Control & $\frac{\text { Long-term debts }}{\text { Total assets }}$ \\
\hline Firm size & FSZ & Control & Log of total assets \\
\hline
\end{tabular}

Source: Various Empirical Studies (2018)

\subsection{Hypotheses}

The hypotheses for the study in their null form are:

$\mathrm{Ho}_{1}$ : There is no significant relationship between non-performing loan ratio and financial performance of Nigerian deposit money banks.

$\mathrm{Ho}_{2}$ : There is no significant relationship between non-performing loan to deposit ratio and financial performance of Nigerian deposit money banks.

$\mathrm{Ho}_{3}$ : There is no significant relationship between capital adequacy ratio and financial performance of Nigerian deposit money banks.

\subsection{Specification of Model}

The specific model for this study is in form of panel methodology and is as stated in equation 3.1a and 3.2b.

$$
\begin{aligned}
& \mathrm{ROA}_{\text {it }}=\beta_{0}+\beta_{1} \mathrm{NPLLR}_{\mathrm{it}+} \beta_{2} \mathrm{NPLDR}_{\text {it }}+\beta_{3} \mathrm{CAR}_{\mathrm{it}}+\beta_{4} \mathrm{FSZ}_{\mathrm{it}}+\beta_{5} \mathrm{LEV}_{\text {it }}+\mathrm{e}_{\mathrm{it}} \quad \text { 3.1a }
\end{aligned}
$$

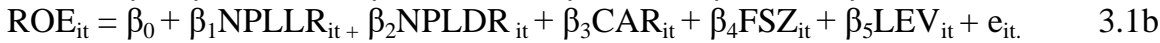

The coefficients of the parameters $\left(\beta_{0}, \ldots . . \beta_{5}\right)$ were estimated using the Fixed effects and Random effects techniques.

\subsection{Validity and Reliability of Data and Research Instrument}

Data used in the study were obtained from a reliable source- audited financial statements of the selected banks. The financial statements were audited by reputable audit firms and certified for public use by relevant regulatory 
bodies, such as Securities and Exchange Commission and Financial Reporting Council of Nigeria. The research instrument adopted for this study is consistent with what obtains in prior empirical studies of this nature (Idowu\&Awoyemi, 2014, Uwuigbe, et al, 2015, Kodithuwakku, 2015, Ogbudu\&Eze, 2016, Mendoza \& Rivera, 2017 and Annor\&Obeng, 2017).

\subsection{EMPIRICAL RESULTS AND DISCUSSION}

\subsection{Descriptive Statistics}

The descriptive statistics of the study are displayed in Table 2. The results indicate that the mean Return on asset (ROA) is $1.1 \%$ with a minimum of $-29.6 \%$ and a maximum of $10.6 \%$. This suggests that on the average, the selected banks make a return of $1.1 \%$ on their total assets, but this increases to a maximum of $10.6 \%$ and as low as $-29.6 \%$. It clearly suggests that the sampled banks are not performing well. The results also show mean Return on equity (ROE) of 0.833 with a minimum of -20.827 and a maximum value of 7.881 .

Table 2: Descriptive Statistics

\begin{tabular}{lllllll}
\hline Variable & Mean & Minimum & Maximum & Std. Deviation & Skewness & Kurtosis \\
\hline ROA & 0.011 & -0.296 & 0.106 & 0.045 & -4.735 & 30.064 \\
ROE & 0.833 & -20.827 & 7.881 & 2.481 & -5.535 & 50.453 \\
NPLLR & 0.107 & 0.004 & 0.869 & 0.163 & 2.984 & 11.939 \\
NPLDR & 0.055 & 0.006 & 0.494 & 0.079 & 3.160 & 13.936 \\
CAR & 0.138 & -0.308 & 0.284 & 0.083 & -2.229 & 12.120 \\
FSZ & 11.930 & 10.551 & 12.920 & 0.463 & -0.593 & 3.013 \\
LEV & 0.057 & 0.000 & 0.684 & 0.080 & 4.506 & 33.571 \\
\hline
\end{tabular}

Source: Authors' computation (2018)

The non-performing loan to total loan ratio (NPLLR) has a mean of $10.7 \%$ with a minimum of $0.4 \%$ and a maximum figure of $86.9 \%$. This suggests that on the average $10.7 \%$ of the total loans and advances granted by banks to customers was bad, while some banks have as low as $0.4 \%$, others have bad debt as high as $86.9 \%$. Of the total deposits made by customers, on the average $5.5 \%$ of which was granted to customers as loans and advances became bad. This rose from $0.6 \%$ to a maximum of $49.4 \%$. Average capital adequacy ratio(CAR) has an average of $13.8 \%$ (more than the CBN's minimum figure for national banks of $10 \%$, but less than that of an international bank of $15 \%$ ). CAR also has a minimum of $-30.8 \%$ and a maximum of $28.4 \%$.

\subsection{Multicollinearity Test}

Variance Inflation Factor (VIF) approach was adopted to test for multicollinearity among the independent variables. The suggested cut-off value for VIF, according to Gujaraji (2003) and Rumsey (2007) is 10.0. As shown in Table 3, the VIF of the three explanatory variables and the two control variables ranges between 1.266 and 5.393; while the average is 2.946. This shows that there is the absence of multicollinearity among the variables.

Table 3: Result of Multicollinearity Test

Source: Authors' computation (2018)

\begin{tabular}{ll}
\hline Variable & VIF \\
\hline NPLLR & 5.393 \\
NPLDR & 4.820 \\
CAR & 1.753 \\
FSZ & 1.266 \\
LEV & 1.498 \\
\hline Average & 2.946 \\
\hline
\end{tabular}

\subsection{Correlation}

Pearson correlation analysis of all the study's variables is presented in Table 4. 
Table 4: Correlation Matrix

\begin{tabular}{|c|c|c|c|c|c|c|c|}
\hline & ROA & ROE & NPLLR & NPLDR & CAR & FSZ & LEV \\
\hline ROA & 1 & & & & & & \\
\hline ROE & $\begin{array}{l}0.775 * * * \\
(0.000)\end{array}$ & 1 & & & & & \\
\hline NPLLR & $\begin{array}{l}0.454 * * * \\
(0.000)\end{array}$ & $\begin{array}{l}0.397 * * * \\
(0.000)\end{array}$ & 1 & & & & \\
\hline NPLDR & $\begin{array}{l}-0.548 * * * \\
(0.000)\end{array}$ & $\begin{array}{l}-0.455^{* * * *} \\
(0.000)\end{array}$ & $\begin{array}{l}0.744 * * * \\
(0.000)\end{array}$ & 1 & & & \\
\hline CAR & $\begin{array}{l}0.521 * * * \\
(0.000)\end{array}$ & $\begin{array}{l}0.308 * * * \\
(0.001)\end{array}$ & $\begin{array}{l}-0.445^{* * * *} \\
(0.000)\end{array}$ & $\begin{array}{l}-0.356^{* * * *} \\
(0.000)\end{array}$ & 1 & & \\
\hline FSZ & $\begin{array}{l}0.178 * \\
(0.052)\end{array}$ & $\begin{array}{l}0.213 * * \\
(0.020)\end{array}$ & $\begin{array}{l}-0.407 * * * \\
(0.000)\end{array}$ & $\begin{array}{l}-0.408 * * * \\
(0.000)\end{array}$ & $\begin{array}{l}-0.006 \\
(0.949)\end{array}$ & 1 & \\
\hline LEV & $\begin{array}{l}-0.224 * * \\
(0.014)\end{array}$ & $\begin{array}{l}-0.094 \\
(0.310)\end{array}$ & $\begin{array}{l}-0.335^{* * * *} \\
(0.000)\end{array}$ & $\begin{array}{l}0.266 * * * \\
(0.003)\end{array}$ & $\begin{array}{l}-0.566^{* * * *} \\
(0.000)\end{array}$ & $\begin{array}{l}-0.023 \\
(0.805)\end{array}$ & 1 \\
\hline
\end{tabular}

$*, * *, * * *$ indicate significant at $10 \%, 5 \%, 1 \%$ levels, respectively

The sig values are in parentheses.

Source: Authors' computation (2018)

It shows that there is a positive association between non-performing loan to total loan ratio (NPLLR) and the two financial performance proxies, Return on asset (ROA) and Return on Equity (ROE) and this is significant at $1 \%$ level. A similar result was obtained between capital adequacy ratio (CAR) and the performance measures. However, non-performing loan to total deposit ratio (NPLDR) has a negative association with the financial proxies and is significant at $1 \%$. This finding clearly indicates that a significant association between the credit risk management indicators and the two performance variables. As for the control variables, there is a positive association between firm size and the two performance proxies. The association is significant at $10 \%$ level with ROA and at 5\% level with ROE. Leverage ratio has a negative association with the two performance proxies but is only significant at $5 \%$ level with ROA.

One of the limitations of the correlation matrix in data analysis is that it only shows the direction of the relationship between two variables; not strength of the relationship. Hence, in line with similar studies conducted in other climes, this study adopted regression analytical approach.

\subsection{Regression}

Table 5 presents the result of the regression based on Fixed effects and Random effects techniques. It demonstrates an agreement in the results of the two approaches. The coefficients of the non-performing loan to total loan ratio (NPLLR) and capital adequacy ratio (CAR) are positively related to performance proxies, ROA and ROE. This indicates a direct relationship between the two credit risk parameters and financial performance. Also, the ratio of non-performing loan to total deposit is negatively related with the two performance proxies.

Table 5: Regression Results

\begin{tabular}{|c|c|c|c|c|}
\hline & Fixed & effects & Random & effects \\
\hline & $\begin{array}{l}\text { Model } 1 \\
\text { (ROA) }\end{array}$ & $\begin{array}{l}\text { Model } 2 \\
\text { (ROE) }\end{array}$ & $\begin{array}{l}\text { Model } 1 \\
\text { (ROA) }\end{array}$ & $\begin{array}{l}\text { Model } 2 \\
\text { (ROE) }\end{array}$ \\
\hline \multirow[t]{3}{*}{ Constant } & -0.380 & -17.214 & -0.166 & -7.567 \\
\hline & $(-1.556)$ & $(-0.987)$ & $(-1.738)^{*}$ & $(-1.219)$ \\
\hline & $\{0.123\}$ & $\{0.326\}$ & $\{0.085\}$ & $\{0.226\}$ \\
\hline \multirow[t]{3}{*}{ NPLLR } & 0.342 & 11.401 & 0.280 & 7.662 \\
\hline & $(5.216)^{* * *}$ & $(2.432)^{* *}$ & $(5.096) * * *$ & $(1.934)^{*}$ \\
\hline & $\{0.000\}$ & $\{0.017)$ & $\{0.000\}$ & $\{0.056)$ \\
\hline \multirow[t]{3}{*}{ NPLDR } & -0.841 & -30.989 & -0.733 & -25.370 \\
\hline & $(-6.635) * * *$ & $(-3.421)^{* * *}$ & $(-6.864) * * *$ & $(-3.283)^{* * *}$ \\
\hline & $\{0.000\}$ & $\{0.001\}$ & $\{0.000\}$ & $\{0.001\}$ \\
\hline \multirow[t]{2}{*}{ CAR } & 0.343 & 12.366 & 0.320 & 9.915 \\
\hline & $(6.984)^{* * *}$ & $(3.521)^{* * *}$ & $(7.298)^{* * *}$ & $(3.149)^{* * *}$ \\
\hline
\end{tabular}




\begin{tabular}{lllll} 
& $\{0.000\}$ & $\{0.001\}$ & $\{0.000\}$ & $\{0.002\}$ \\
FSZ & 0.029 & 1.384 & 0.012 & 0.614 \\
& $(1.438)$ & $(0.949)$ & $(1.508)$ & $(1.219)$ \\
LEV & $\{0.154\}$ & $\{0.345\}$ & $\{0.134\}$ & $\{0.225\}$ \\
& 0.059 & 5.560 & 0.078 & 5.020 \\
& $(1.002)$ & $(1.315)$ & $(1.761)^{*}$ & $(1.633)$ \\
$\mathrm{R}^{2}$ & $\{0.319\}$ & $\{0.192\}$ & $\{0.081\}$ & $\{0.105\}$ \\
Adjusted $\mathrm{R}^{2}$ & 0.678 & 0.468 & 0.564 & 0.277 \\
Durbin-Watson & 0.592 & 0.327 & 0.545 & 0.245 \\
F-stat & 2.542 & 3.103 & 2.322 & 2.636 \\
& $7.909 * * *$ & $3.308^{* * * *}$ & $29.530 * * *$ & $8.732^{* * * *}$ \\
No of observations & $\{0.000\}$ & $\{0.000\}$ & $\{0.000\}$ & $\{0.000\}$ \\
\hline
\end{tabular}

$*, * *, * * *$ indicate significant at $10 \%, 5 \%, 1 \%$ levels, respectively

The prob values are in parentheses style \{\} while $t$-stat values are in parentheses style ( ).

Source: Researchers' computation (2018)

\subsection{Hausman's Specification}

In order to determine which of the results of the two regressions (Fixed effects and Random effects models) is appropriate for purpose of valid inference, the Hausman's(1978) specification test was conducted. Table 6 presents the result of Hausman's specification test.

Table 6:Hausman's Specification Result

\begin{tabular}{lllll}
\hline Model & $\begin{array}{l}\text { Dependent } \\
\text { Variable }\end{array}$ & $\begin{array}{l}\text { Chi-Square } \\
\text { Statistic }\end{array}$ & Chi-Square d. f & Probability \\
\hline 1 & ROA & 5.193 & 5 & 0.393 \\
2 & ROE & 4.742 & 5 & 0.448 \\
\hline
\end{tabular}

Source: Authors' computation (2018)

According to Gujarati and Porter (2009), when the p-value is significant at 5\% level, the Fixed effects model is more appropriate for valid inferences to be made. However, if the p-value is not significant at $5 \%$, then the Random effects model is suitable to be used for inference.

The results of the p-values for the two models as shown in Table 6 are greater than $5 \%$, hence the discussion of regression results was made using the outcome of the Random effects model

\subsection{Discussion of Regression Result}

The result of the regression for Model 1 in Table 6 provides that the coefficient of determination (R-square) of $0.564(56.4 \%)$ and Adjusted R-square of $0.545(54.5 \%)$ indicating that $56.4 \%$ variation in the dependent variable (ROA) is explained by the explanatory and control variables (NPLLR, NPLDR, CAR, FSZ and LEV). The Durbin-Watson value of 2.322 (which falls within the acceptable region) clearly shows the absence of autoserial correlation in the successive values of the parameters.F-statistic is 29.530 and this is significant at $1 \%$ level $(\mathrm{p}=0.000)$. This affirms that the model as a whole is jointly fit. Hence, the explanatory values are significantly linked with the dependent variable.

From Table 6, the relationship between NPLLR and ROA is positive and significant at $1 \%$ level. It indicates that the higher the bad debts, the higher the profits of Nigerian banks. This finding to some extent is contrary to the theoretical expectation of negative relationship between the two variables. The possible reason for this result is the tendency of Nigerian banks to transfer costs associated with loan default to other customers. In some cases, Nigerian banks' interest rate on loan is as high as $25 \%$ per annum (excluding other administrative charges). This high rate is used as a buffer to mitigate the huge non-performing loans from other customers in their books. The outcome of this study is consistent with the works of Boahene, Dasah and Agyei (2012), Afriyie and Akotey (2013), Idowu and Awoyemi (2014), Soyemi, Ogunleye and Ashogbon (2014), Kurawa and Garba (2014), Annor and Obeng (2017), Aigbomian and Akinlosotu(2017) and Okere, et al (2018) and provides evidence in support of Signaling Hypothesis. This result, however, contradicts the findings of Lata(2014), Uwuigbe, Uwuigbe and Oyewo (2015), Mubbushar (2016), Adebayo and Oluwaremi, 2017, Mendoza and Rivera (2017) and Lawal et al (2017) which showed a negative significant relationship between the two variables. The null 
hypothesis 1 is hereby rejected. Thus, there is a significant relationship between non-performing loan to total deposit ratio (NPLDR) and performance (ROA).

The NPLDR has a negative and significant relationship with ROA at $1 \%$ level. This is in agreement with theoretical expectation. It suggests that as the NPLDR is increasing, the ROA is reducing. This outcome is in agreement with the findings of Kargi (2011), Nawaz and Munir (2012), Kolapo et al (2012) and Kani (2017). The null hypothesis 2 is therefore rejected. Thus, there is a significant relationship between non-performing loan to total deposit ratio (NPLDR) and performance (ROA).

The CAR has a positive relationship with ROA and is significant at1\% level. This confirms the theoretical expectation that says that banks with excellent capital adequacy tend to have excellent profitability because such banks will be strong enough to avert unforeseen bank run and huge loan default by customers. The outcome of the study is in line with the findings of Vong and Chan (2009), Roman and Danulletiu (2013), Obamuyi (2013), Ogboi and Unuafe (2013), Soyemi et al (2014),Mubbushar (2016), Annor and Obeng (2017), Mamoud-Abdul (2017), Lotto(2018) and Okere, et al (2018). It is however in contrast with the findings of Idowu and Awoyemi (2014), Kurawa and Garba (2014), Mendoza and Rivera (2017), who found a positive and insignificant relationship and that of Djan, Stephen, Bawuah, Halidu and Kuutol (2015), who found a negative and significant relationship, between the two variables in their studies. The null hypothesis 3 is rejected. Thus, there is a significant relationship between capital adequacy ratio (CAR) and performance (ROA).

As for the control variables, firm size has a positive and insignificant relationship with ROA, Leverage, in support of the prediction of Static-trade off theory, has a positive and significant relationship at $10 \%$ level with ROA (Myers\&Majluf, 1984,Kyereboah-Coleman, 2007, Kajola, 2015 and Onaolapo, Kajola \& Nwidobie, 2015).

It is seen from Table 6 that for Model 2, R-squared is 0.277; Adjusted R-squared (0.245), Durbin Watson (2.636) and F-statistic $(8.732$; prob value $=0.000)$. These results indicate that there is absence of serial autocorrelation in the study variables and the model is a good fit.

It is pertinent to note that there is an agreement in the results of models 1 and 2 regarding the direction and strength of the relationship between the credit risk management variables and the financial performance measure, ROE. NPLLR and CAR have a positive and significant relationship with ROE at $10 \%$ and $1 \%$ levels, respectively. However, NPLDR has a negative and significant relationship with ROE at $1 \%$ level. The two control variables, FSZ and LEV have positive but no significant relationship with ROE.

By combining the findings of the study in Models 1 and 2, the current study provides evidence that credit risk management practices have a significant effect on the financial performance of banks. This is finding is in agreement with some prior empirical studies (Kargi, 2011, Soyemi, et al, 2014, Lata, 2014, Ogbulu\&Eze, 2016, Ugoani, 2016, Muriithi, 2016, Lawal, et al, 2017, Lotto, 2018 and Okere, et al, 2018).

\subsection{CONCLUSION AND RECOMMENDATIONS}

\subsection{Conclusion}

The study empirically examined the effect of credit risk management on the financial performance of ten listed deposit money banks in Nigeria. The period of study spanned 12 years (2005-2016). Three variables, nonperforming loan to total loan ratio (NPLLR); non-performing loan to deposit ratio (NPLDR) and capital adequacy ratio (CAR) were used as surrogates for credit risk management practices. For financial performance, two accounting measures, Return on asset (ROA) and Return on equity (ROE) were used as proxies. With the use of Random effects generalised least squares (GLS) regression as data estimation technique, the study produced a significant relationship between NPLLR, NPLDR and CAR and the two performance proxies, ROA and ROE. The finding of the study support that credit risk management practices have a significant effect on the financial performance of banks.

In line with the outcome of the study, it is recommended that banks 'management should endeavour to develop rigorous and robust credit policies that will enable them to efficiently and effectively assess the creditworthiness of their customers. The use of information provided by independent credit bureau and credit rating organisations on the prospective customer that seeks loan facility should be encouraged. Capital adequacy of the various banks should be closely monitored in such a way that it will not be less than the minimum Central Bank of Nigeria provision. With this, the financial health and strength will not be jeopardised. There is also a need for banks' management to diversify their source of income base. This is because over-reliance on interest income from loans and advances may not produce adequate returns necessary to compensate providers of capital in the sector. The regulatory agencies, particularly the Central Bank of Nigeria and Nigeria Deposit Insurance 
Corporation, should come up with modern credit risk measurements, identification and control. Prompt and necessary action should also be taken against the management of any bank that flout their credit risk regulations in order to avoid unpleasant distress in the financial system.

\section{$5.2 \quad$ Suggestions for Future Studies}

For future studies, efforts should be made to increase sample size and time frame. Other variables that can be used to proxy credit risk management can also be adopted. The need to extend this type of study to other business sectors (conglomerates, construction, insurance, services, oil and gas, etc) is also suggested.

\section{References}

[1]. Adebayo, A. O. \&Oluwaremi, F. (2017). Relationship between credit risk management and the performance of money deposit banks in Nigeria. IOSRJournal of Economics and Finance, 8(2), 38-48.

[2]. Afriyie, H. O. \&Akotey, J. O. (2013).Credit risk management and profitability of rural banks in the BrongAhafo Region of Ghana.European Journal of Business and Management, 5(24), 24-33.

[3]. Aigbomian, E. \&Akinlosotu, N. T. (2017).Credit risk management and profitability of deposit money banks in Ekpoma, Edo State.Journal of Economics and Sustainable Development, 8(3), 1-5.

[4]. Alshatti, A. S. (2015). The effect of credit risk management on financial performance of Jordanian commercial banks.Investment Management and Financial Innovations, 12 (1 \& 2), 338-345.

[5]. Annor, E. S., \&Obeng, F. S. (2017). Impact of credit risk management on the profitability of selected commercial banks listed on the Ghana stock exchange. Journal of Economics, Management and Trade, 20(2), 110.

[6]. Asfaw, A. H. \&Veni, P. (2015).Empirical study on credit risk management practice of Ethiopian commercial banks.Research Journal of Finance and Accounting, 6(3), 134-147.

[7]. Aykut, E. (2016). The effect of credit and market risk on bank performance: Evidence from Turkey. International Journal of Economics and Financial Issues, 6(2), 427-434.

[8]. Basel Committee on Banking Supervision (2001). Risk management practices and regulatory capital: Crosssectional comparison. Available on-line: www.bis.org.

[9]. Boahene, S. H., Dasah, J., \&Agyei, S. K. (2012).Credit risk and profitability of selected banks in Ghana.Research Journal of Finance and Accounting, 3(7), 6-14.

[10]. Djan, G. O., Stephen, F., Bawuah, J., Halidu, O. B.\&Kuutol, P. K. (2015).Credit risk management and its impact on financial performance of listed banks in Ghana.International Journal of Financial Markets, 2(2), 2432.

[11]. Edwards, P.\& Turnbull, A. (1994). Finance for small and medium sized enterprises, information and the income gearing challenge. International Journal of Marketing, 12(6), 3-9.

[12]. Ejoh, N. O., Okpa, I. B. \&Egbe, A. A. (2014). The impact of credit and liquidity risk management on the profitability of deposit money banks in Nigeria.International Journal of Economics, Commerce and Management, 2(9), 1-15.

[13]. E-Views 10.0: User's Guide.

[14]. Greuning, H. \&Bratanovic, S. B. (2003).Analysing and Managing Banking Risk: A Framework for Assessing Corporate Governance and Financial Risks. $2^{\text {nd }}$ Edition, Washington, D. C: The World Bank.

[15]. Gujarati, D. N. (2003).Basic Econometrics, New York: McGraw-Hill/Irwin.

[16]. Gujarati, D. N.\& Porter, D. C. (2009). Basic Econometrics, New York: McGraw-Hill/Irwin.

[17]. Harcourt, E. E. (2017). Credit risk management and performance of deposit money banks in Nigeria.International Journal of Managerial Studies and Research, 5(8), 47-57.

[18]. Hausman, J. A. (1978). Specification tests in econometrics.Econometrica, 46(6), 1215-1271.

[19]. IBM SPSS Version 20.0

[20]. Idowu, A. \&Awoyemi, S. O. (2014).The impact of credit risk management on the commercial banks performance in Nigeria.International Journal of Management and Sustainability, 3(5), 295-306.s

[21]. Kajola, S. O. (2015). Determinants of capital structure of Nigerian quoted companies. Unpublished Ph. D Thesis, LadokeAkintola University of Technology, Ogbomoso, Nigeria.

[22]. Kani, S.. (2017). Credit risk and banks performance: Evidence from WAEMU countries. IOSR Journal of Economics and Finance, 8(1), 5-11.

[23]. Kargi, H. S. (2011). Credit risk and the performance of Nigerian banks.Unpublished article, Department of Accounting, Faculty of Administration, Ahmadu Bello University, Zaria, Nigeria.

[24]. Kodithuwakku, S. (2015).Impact of credit risk management on the performance of commercial banks in Sri Lanka.International Journal of Scientific Research and Innovative Technology, 2(7), 24-29.

[25]. Kolapo, T. F., Ayeni, R. K., \&Oke, M. O. (2012). Credit risk and commercial banks' performance in Nigeria: A panel model approach. Australian Journal of Business and Management Research, 2(2), 31-38.

[26]. Kurawa, J. M. \&Garba, S. (2014). An evaluation of the effect of credit risk management on the profitability of Nigerian banks.Journal of Modern Accounting and Auditing, 10(1), 104-115.

[27]. Kyereboah-Coleman, A. (2007). The impact of capital structure on the performance of microfinance institutions.Journal of Risk Finance, 8, 56-71.

[28]. Lata, R. G. (2014). Non-performing loan and its impact on profitability of state-owned commercial banks in Bangladesh: An empirical study. Proceedings of $11^{\text {th }}$ Asian Business Research Conference, BIAM Foundation, Dhaka, Bangladesh, 26-27, December. 
[29]. Lawal, A. A., Abiola, B. I., \&Ikhu-Omoregbe, S. (2017). Effect of credit risk management on performance of listed Nigerian deposit money banks.ICAN Journal of Accounting \& Finance, 6(1), 167-195

[30]. Lotto, J. (2018). The empirical analysis of the impact of bank capital regulations on operating efficiency.International Journal of Financial Studies, 6(34), 1-11.

[31]. Mamoud-Abdul, J. (2017). Impact of capital adequacy on the performance of Nigerian banks using the Basel accord framework.East Africa Research Papers in Business, Entrepreneurship and Management. EARP-BEM No. 2017: 07.

[32]. Mendoza, R. \& Rivera, J. P. R. (2017).The effect of credit risk and capital adequacy on the profitability of rural banks in the Philippines.Scientific Annals of Economics and Business, 64(1), 83-96.

[33]. Mubbushar, I. (2016). Impact of credit risk management on financial performance of commercial banks in Pakistan.University of Haripur Journal of Management, 1(2), 110-124.

[34]. Muriithi, J. G., Waweru, K. M. \&Muturi, W. M. (2016).Effect of credit risk on financial performance of commercial banks in Kenya.IOSR Journal of Economics and Finance, 7(4), 72-83.

[35]. Myers, S. C. (1984). The capital structure puzzle.Journal of Finance, 39, 575-592.

[36]. Myers, S. C.\&Majluf, N. (1984). Corporate financing and investment decisions when firms have information that investors do not have.Journal of Financial Economics, 13, 187-221.

[37]. Nawaz, M. \&Munir, S. (2012). Credit risk and the performance of Nigerian banks.Interdisciplinary Journal of Contemporary Research in Business, 4(7), 49-61.

[38]. Nigerian Stock Exchange (2005-2016). Fact Book, Lagos.

[39]. Obamuyi, T. M. (2013). Determinants of banks' profitability in a developing economy: Evidence from Nigeria. Organisations and Markets in Emerging Economies, 4(2), 97-111.

[40]. Ogboi, C. \&Unuafe, O. K. (2013).Impact of credit risk management and capital adequacy on the financial performance of commercial banks in Nigeria.Journal of Emerging Issues in Economics, Finance and Banking, 2(3), 703-717.

[41]. Ogbulu, O. M. \&Eze, G. P. (2016). Credit risk management and the performance of deposit money banks in Nigeria: An error correction analysis. Applied Economics and Finance, 3(2), 97-109.

[42]. Okere, W., Isiaka, M. A. \&Ogunlowore, A. J. (2018).Risk management and financial performance of deposit money banks in Nigeria.European Journal of Business, Economics and Accountancy, 6(2), 30-42.

[43]. Okoye, V., \&Eze, O. R. (2013).Effect of bank lending rate on the performance of Nigerian deposit money banks.International Journal of Business and Management Review, 1(1), 34-43.

[44]. Olokoyo, F. O. (2011). Determinants of commercial banks' lending behaviour in Nigeria.International Journal of Financial Research, 2(2), 61-72.

[45]. Onaolapo, A.A., Kajola, S.O.,\&Nwidobie, M.B. (2015). Determinants of capital structure: a study of Nigerian quoted companies. European Journal of Business and Management, 7(23), 170-183.

[46]. Poudel, R. P. (2012). The impact of credit risk management on financial performance of commercial banks in Nepal.International Journal of Arts and Commerce, 1(5), 9-15.

[47]. Roman, A. \&Danuletiu, A. E. (2013).An empirical analysis of the determinants of bank profitability in Romanian.Annales Universitatis Apulensis Series Oeconomica, 15(2), 580-593.

[48]. Rumsey, D. (2007).Intermediate Statistics for Dummies, Indianapolis, Wiley Publishing Inc.

[49]. Singh, A. (2015). Performance of credit risk management in Indian commercial banks.International Journal of Managerial Business Research, 5(3), 169-188.

[50]. Soyemi, K. A., Ogunleye, J. O., \&Ashogbon, F. O. (2014). Risk management practices and financial performance: Evidence from the Nigerian deposit money banks. The Business and Management Review, 4(4), 345-354.

[51]. Ugoani, J. N. N. (2016). Nonperforming loans portfolio and its effect on bank profitability in Nigeria. Independent Journal of Management \& Production, 7(2), 303-319.

[52]. Uwuigbe, U., Uwuigbe, O. R., \&Oyewo, B. (2015).Credit management and bank performance of listed banks in Nigeria.Journal of Economics and Sustainable Development, 6(2), 27-32.

[53]. Vong, A. \& Chan, H. S. (2009).Determinants of bank profitability in Macao.Available at http://www.amcm.gov.mo/publication/quarterly/March2018/macaoprof_en.pdf.

\section{Appendix I: List of Sampled Nigerian Deposit Money Banks}

\begin{tabular}{|l|l|}
\hline S/N & Name of Firm \\
\hline 1 & Access Bank Plc \\
\hline 2 & Fidelity Bank Plc \\
\hline 3 & Wema Bank Plc \\
\hline 4 & Diamond Bank Plc \\
\hline 5 & First Bank Plc \\
\hline 6 & Zenith Bank Plc \\
\hline 7 & GT Bank Plc \\
\hline 8 & UBA Plc \\
\hline 9 & FCMB Plc \\
\hline 10 & Union Bank Plc \\
\hline
\end{tabular}

